Review Articles

\title{
Molecular Pathogenesis of Secondary Acute Promyelocytic Leukemia.
}

Melanie Joannides ${ }^{1}$, Ashley N Mays ${ }^{1}$, Anita R Mistry ${ }^{1}$, Syed Khizer Hasan ${ }^{2}$, Andreas Reiter ${ }^{3}$, Joseph L Wiemels ${ }^{4}$, Carolyn A Felix ${ }^{5}$, Francesco Lo Coco $^{2}$, Neil Osheroff ${ }^{6}$, Ellen Solomon ${ }^{1}$ and David Grimwade ${ }^{1}$

${ }^{1}$ Department of Medical \& Molecular Genetics, King's College London School of Medicine, UK.

${ }^{2}$ Department of Biopathology \& Fondazione Santa Lucia, University of Tor Vergata, Rome, Italy.

${ }^{3}$ III.Medizinische Klinik,Universitätsmedizin Mannheim, Mannheim, Germany.

${ }^{4}$ Department of Epidemiology and Biostatistics, University of California, San Francisco, San Francisco, USA.

${ }^{5}$ Division of Oncology, Children's Hospital of Philadelphia, Philadelphia, USA.

${ }^{6}$ The Departments of Biochemistry and Medicine, Vanderbilt University School of Medicine, Nashville, USA.

Correspondence to: David Grimwade, Cancer Genetics Lab, Dept. of Medical \& Molecular Genetics, $8^{\text {th }}$ Floor, Tower Wing, Guy's Hospital, London SE1 9RT, UK. Tel: +44 207188 3699, Fax: +44 207188 2585. E-mail: david.grimwade@genetics.kcl.ac.uk

Competing interests: The authors have declared that no competing interests exist.

Published: October 24, 2011

Received: August 25, 2011

Accepted: September 20, 2011

Mediterr J Hematol Infect Dis 2011, 3(1): e2011045, DOI 10.4084/MJHID.2011.045

This article is available from: http://www.mjhid.org/article/view/9085

This is an Open Access article distributed under the terms of the Creative Commons Attribution License (http://creativecommons.org/licenses/by/2.0), which permits unrestricted use, distribution, and reproduction in any medium, provided the original work is properly cited.

Abstract: Balanced chromosomal translocations that generate chimeric oncoproteins are considered to be initiating lesions in the pathogenesis of acute myeloid leukemia. The most frequent is the $\mathrm{t}(15 ; 17)(\mathrm{q} 22 ; \mathrm{q} 21)$, which fuses the $P M L$ and $R A R A$ genes, giving rise to acute promyelocytic leukemia (APL). An increasing proportion of APL cases are therapy-related (t-APL), which develop following exposure to radiotherapy and/or chemotherapeutic agents that target DNA topoisomerase II (topoII), particularly mitoxantrone and epirubicin. To gain insights into molecular mechanisms underlying the formation of the $t(15 ; 17)$ we mapped the translocation breakpoints in a series of $t$-APLs, which revealed significant clustering according to the nature of the drug exposure. Remarkably, in approximately half of t-APL cases arising following mitoxantrone treatment for breast cancer or multiple sclerosis, the chromosome 15 breakpoint fell within an 8-bp "hotspot" region in $P M L$ intron 6, which was confirmed to be a preferential site of topoII-mediated DNA cleavage induced by mitoxantrone. Chromosome 15 breakpoints falling outside the "hotspot", and the corresponding $R A R A$ breakpoints were also shown to be functional topoII cleavage sites. The observation that particular regions of the $P M L$ and $R A R A$ loci are susceptible to topoII-mediated DNA damage induced by epirubicin and mitoxantrone may underlie the propensity of these agents to cause APL.

Introduction. Acute myeloid leukemia (AML) is characterized by a spectrum of recurring chromosomal abnormalities, which distinguish biologically and prognostically distinct subtypes of disease (reviewed ${ }^{1}$ ). 
To date, more than one hundred balanced chromosomal rearrangements (translocations, insertions and inversions) have been identified and cloned, ${ }^{2}$ with evidence suggesting that these are critical initiating events in the pathogenesis of AML. Identification of the genes involved in chromosomal rearrangements has provided major insights into the regulation of normal hematopoiesis and how disruption of key transcription factors and epigenetic modulators promote leukemic transformation. A number of genes, including $M L L$ at $11 \mathrm{q} 23, N U P 98$ at $11 \mathrm{p} 15, R A R A$ at $17 \mathrm{q} 21$ and $R U N X 1$ at $21 \mathrm{q} 22$, are recurrent targets of chromosomal rearrangements in AML, being fused to a range of potential partner genes (reviewed ${ }^{3}$ ). Interestingly, chromosomal rearrangements involving these particular loci also have been noted as a feature of secondary acute leukemias arising as a complication of prior therapy involving drugs targeting topoisomerase II (topoII), which are widely used in the treatment of a variety of tumors. ${ }^{4-13}$ TopoII is a critical enzyme that relaxes supercoiled DNA and removes knots and tangles from the genome by transiently cleaving and religating both strands of the double helix via the formation of a covalent cleavage intermediate (reviewed ${ }^{14}$ ). Epipodophyllotoxins (e.g. etoposide), anthracyclines (e.g. epirubicin) and anthracenediones (e.g. mitoxantrone) act as topoII poisons, inducing DNA damage by disrupting the cleavage-religation equilibrium and increasing the concentration of DNA topoII covalent complexes, which leads to apoptosis of the tumor cells. ${ }^{14}$

The association between exposure to chemotherapeutic agents targeting topoII and development of leukemias with balanced chromosomal rearrangements has naturally implicated the enzyme in this process, but the mechanisms involved have remained subject to debate. One hypothesis takes into account reports that leukemia-associated translocations can be detected in hematopoietic cells derived from healthy individuals without overt leukemia, ${ }^{15,16}$ suggesting that administration of chemotherapy and/or radiotherapy provides a selective advantage to progenitors with pre-existing translocations during regrowth of depopulated bone marrow. Moreover, the exposure to DNA damaging agents could lead to the acquisition of additional mutations that cooperate with the chimeric fusion protein generated by the translocation to induce leukemic transformation. A second hypothesis, based on findings with transformed cells, raised the possibility that agents targeting topoII could lead to the formation of chromosomal translocations through an indirect mechanism involving induction of apoptotic nucleases. ${ }^{17-20}$ Interestingly, Rolf Marschalek and colleagues provide evidence for a third potential mechanism, showing that the region of the
$M L L$ locus where breakpoints associated with infant and therapy-related leukemias cluster, colocalize with an internal promoter element, highlighting the relevance of chromatin structure and DNA topology in the genesis of chromosomal translocations. ${ }^{21}$ Finally, the fourth hypothesis, which is based on increasing biochemical and genetic evidence, suggests that in the presence of a topo II-targeting chemotherapeutic agent, topoII plays a direct role in generating double-stranded DNA breaks in regions of the genome that are particularly susceptible due to the nature of the surrounding chromatin. Following aberrant repair, these breaks go on to generate leukemia-associated chromosomal translocations (reviewed ${ }^{22}$ ).

Intriguingly, the nature of the drug exposure has a bearing on the molecular phenotype of the resultant secondary leukemia, with translocations involving the $M L L$ gene at $11 \mathrm{q} 23$ being particularly associated with etoposide exposure. ${ }^{10,23,24}$ Development of therapyrelated acute promyelocytic leukemia (t-APL), characterized by the $\mathrm{t}(15 ; 17)(\mathrm{q} 22 ; \mathrm{q} 21)$, has been linked to treatment with mitoxantrone and epirubicin. ${ }^{12,25,26}$ The $t(15 ; 17)$ leads to fusion of the gene encoding the myeloid transcription factor RAR $\alpha$ (Retinoic Acid Receptor Alpha) at $17 \mathrm{q} 21$ with a gene that was previously unknown - designated $P M L$ (for ProMyelocytic Leukemia), which has subsequently been found to be involved in growth suppression and regulation of apoptosis (reviewed ${ }^{27}$ ). This subtype of leukemia is of particular interest, being the first in which molecularly targeted therapies (i.e., alltransretinoic acid [ATRA] and arsenic trioxide [ATO]) have been successfully used in clinical practice. ${ }^{27}$ These agents act by inducing degradation of the PMLRAR $\alpha$ oncoprotein, leading to clinical remission and have resulted in dramatic improvements in clinical outcome (reviewed ${ }^{28}$ ). They also offer a potentially curative approach in patients with t-APL who have already received significant doses of chemotherapy for their previous condition and may be close to the anthracycline ceiling, or who are considered unfit for conventional therapy. ${ }^{29}$

The majority of t-APL cases arise in patients who have undergone treatment for breast cancer, where mitoxantrone and epirubicin have been widely used. $^{12,25,26,30}$ In this setting, cumulative doses of epirubicin of $\leq 720 \mathrm{mg} / \mathrm{m}^{2}$ have been associated with a secondary leukemia risk of $0.37 \%$ at 8 years. ${ }^{31}$ As more patients survive their primary cancers, secondary leukemias are becoming an increasing healthcare problem. $^{32}$ Although t-APL remains relatively uncommon, two case series have suggested that the incidence has risen in recent years, with up to $20 \%$ of APL patients presenting with secondary disease. ${ }^{25,30}$ 


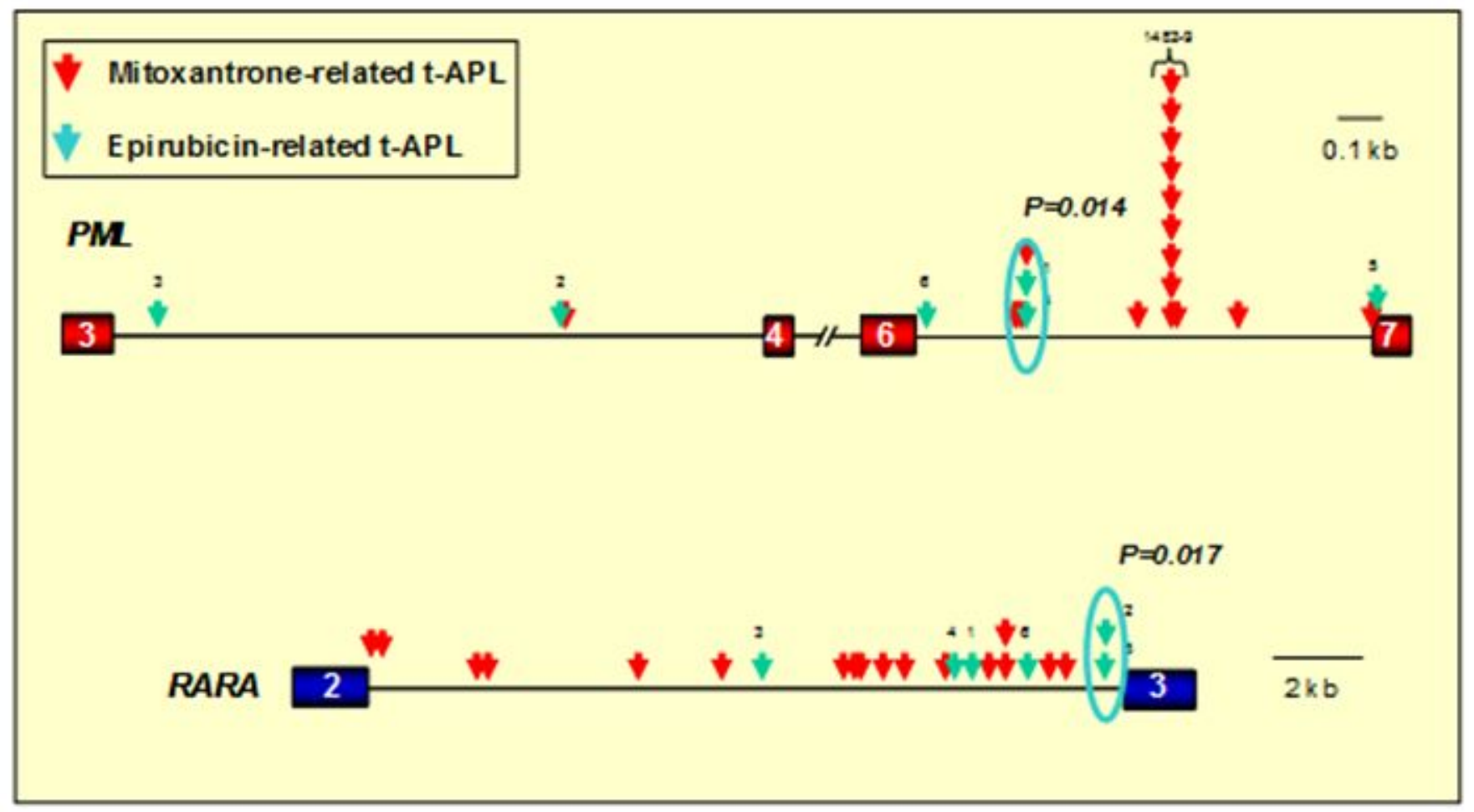

Figure 1. Distribution of translocation breakpoints within the $P M L$ and $R A R A$ loci in $\mathrm{t}-\mathrm{APL}$ cases arising following epirubicin and mitoxantrone. $P M L$ exons are represented by red boxes, $R A R A$ exons in blue and introns are represented by black lines. Arrows indicate the location of PML and RARA translocation breakpoints identified by long-range PCR and sequence analysis in patients with t-APL arising following mitoxantrone (red arrows) or epirubicin (green arrows). In 12 patients mitoxantrone was used for treatment of multiple sclerosis (MS). In the remaining 5 patients with mitoxantrone-related APL and the 6 patients with t-APL following epirubicin, these agents were used for prior breast cancer. Significant breakpoint clustering was observed, with a "hotspot" identified in PML intron 6 (position 1482-9) in mitoxantrone-related APL (following use of the drug for MS or breast cancer) and separate clusters associated with APL arising following epirubicin exposure. Chromosomal breakpoints were confirmed to be preferential sites of drug-induced topoisomerase II cleavage in functional assays (see Figure 2). Adapted from Mays et $\mathrm{al}^{42}$ with permission.

Investigation of Molecular Mechanisms in Mitoxantrone-Related t-APL. As a first step to gain insights into mechanisms underlying formation of the $t(15 ; 17)$ we used long-range polymerase chain reaction (PCR) and sequence analysis to define chromosomal breakpoint locations, comparing the pattern between patients presenting de novo $(\mathrm{n}=35)$ and those with $\mathrm{t}$ APL occurring following exposure to mitoxantrone $(n=6)$ or other agents/radiation therapy $(n=7) .{ }^{33}$ Analysis of diagnostic samples from large cohorts of patients with de novo APL has established that the majority of chromosome 15 breakpoints fall within 3 breakpoint cluster regions (bcr) i.e. in intron 3 (bcr3), intron 6 (bcr1) and exon 6 (bcr2) of the PML locus, accounting for approximately $40 \%, 55 \%$ and $5 \%$ of cases respectively. ${ }^{34}$ Chromosome 17 breakpoints fall within the $\sim 17 \mathrm{~kb}$ intron 2 of the RARA locus, such that the PML-RAR $\alpha$ fusion retains key functional domains mediating DNA binding and interaction with coactivator/corepressors, retinoid-X-receptor and ligand (i.e. retinoic acid). ${ }^{27}$ While breakpoints observed in de novo APL appeared broadly distributed, chromosome 15 breakpoints of each of the mitoxantrone-related t-APLs fell within PML intron 6, with 4 cases clustering within an 8-bp region (position 1482-9)(see Figure 1). ${ }^{33}$ Given that this intron is over $1 \mathrm{~kb}$ in length, this clustering of breakpoints was highly unlikely to have occurred by chance $(\mathrm{p}<0.001$ by scan statistics). To investigate this further, we used a functional in vitro assay, in which substrates containing the normal homologues of the PML and RARA translocation breakpoints are 5'-end-labelled and exposed to clinically relevant topoII poisons (e.g. mitoxantrone, epirubicin, etoposide) in the absence or presence of human topoII alpha; cleavage complexes are trapped and cleavage sites mapped in relation to the observed translocation breakpoints at the sequence level. ${ }^{35-37}$ These experiments demonstrated that the breakpoint "hotspot," identified in t-APL patients previously treated with mitoxantrone for breast cancer, corresponded precisely to a preferential mitoxantroneinduced topoII-dependent DNA cleavage site at position 1484 (see Figure 2). ${ }^{33}$ Moreover, each observed translocation breakpoint within the RARA locus on chromosome 17 was confirmed to be a preferred site of topoII-mediated DNA damage induced by mitoxantrone (Figure 2). ${ }^{33}$

These data strongly implicated mitoxantrone in the etiology of t-APL. However, it is important to consider that the study of patients developing leukemia 
A

B

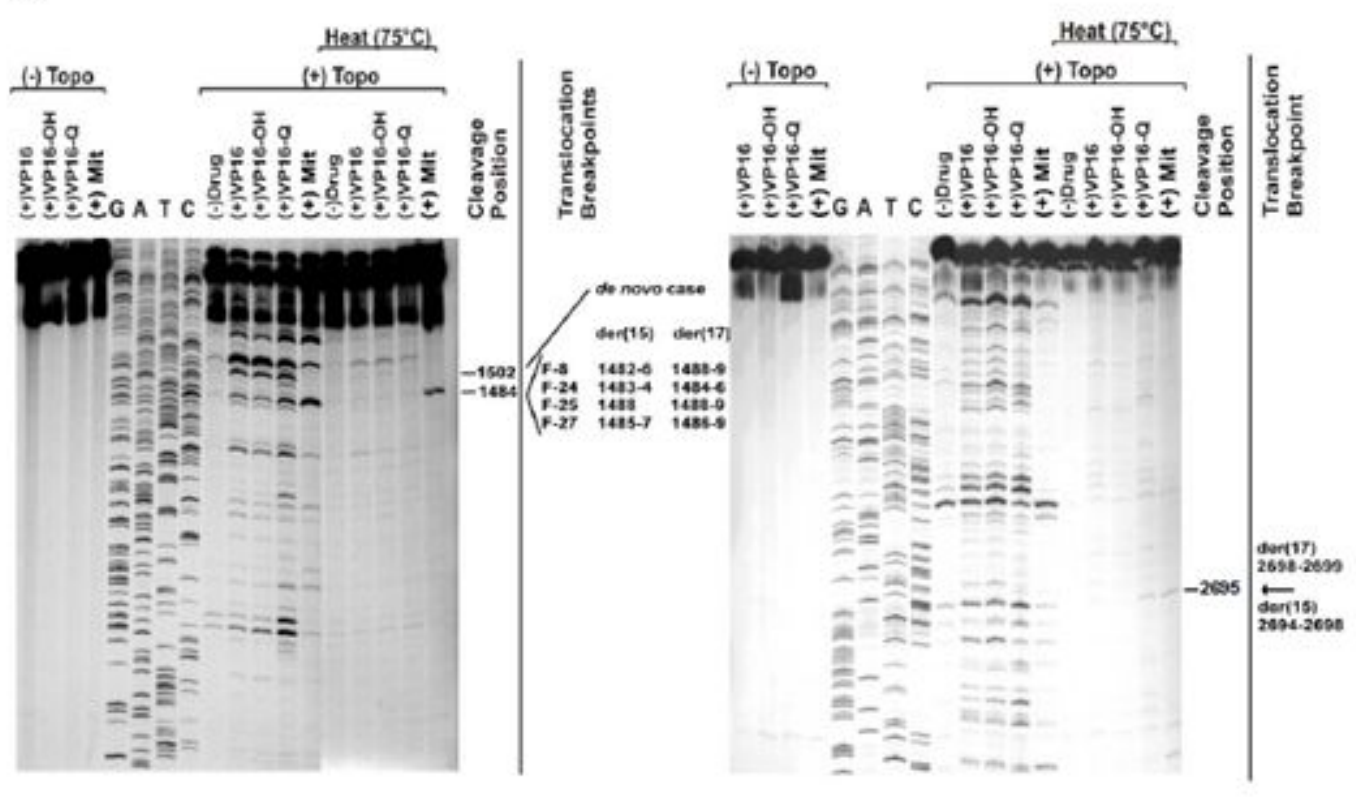

Figure 2. Demonstration of mitoxantrone-induced topoisomerase II dependent DNA cleavage at translocation breakpoints in therapy-related APL. A) In vitro DNA topoisomerase II (topoII) cleavage assay carried out for a PML substrate containing the breakpoints of 4 treatmentrelated APL (t-APL) cases (F-8,-24,-25,-27) within the 8-bp breakpoint "hotspot" (positions 1482-1489). Patients received combination chemotherapy including the topoII poison mitoxantrone for breast cancer. Control reactions were carried out in the absence of topoII (lanes 1-4), and in the presence of etoposide (VP16), etoposide catechol (VP16-OH), etoposide quinone (VP16-Q) and mitoxantrone (Mit). Dideoxy sequencing reactions of the substrate are shown in lanes 5-8. Cleavage reactions were carried out by exposure to human topoII $\alpha$ in the absence of drug (lane 9), and in the presence of etoposide (lane 10), etoposide catechol (lane 11), etoposide quinone (lane 12) and mitoxantrone (lane 13). Additional cleavage reactions were carried out to evaluate the heat-stability of cleavage complexes formed by incubation at $75^{\circ} \mathrm{C}$ for $10 \mathrm{~min}$ (lanes $14-18$ ). The nucleotide shown by the dash is the 5 'side of the cleavage site (-1 position), which corresponds to the der(15) and der(17) translocation breakpoints in 4 cases of mitoxantrone-related APL (far right). The cleavage site at position 1484 was observed in the absence of drug, and in the presence of etoposide, both etoposide metabolites and mitoxantrone (lanes 913). Cleavage at this position was the strongest site observed in the presence of mitoxantrone (lane 13). Furthermore, the complexes formed at this site were shown to be heat-stable in the presence of mitoxantrone (lane 18). Interestingly, a cleavage site at position 1502 is also observed, which corresponds to a breakpoint detected in a case of de novo APL.

B) TopoII cleavage assay of normal homologue of $\operatorname{der}(15)$ and $\operatorname{der}(17) R A R A$ translocation breakpoints in APL of one of the mitoxantronerelated cases (F-8). The substrate spanning positions 2603 to 2871 of $R A R A$ intron 2 contained the translocation breakpoints. Dash at right shows (-1) position of cleavage site corresponding to der(15) and der(17) translocation breakpoints (arrow far right). Adapted from Mistry et al. ${ }^{33}$ with permission.

following cancer therapy presents a challenge, given that they have often been exposed to multiple cytotoxic drugs in addition to radiotherapy. This makes it difficult to identify the causative agent with any certainty. Moreover, such patient populations could feasibly be enriched for individuals at particular risk of leukemia, having already developed one form of cancer. Therefore, to provide further insights into molecular mechanisms in topoII-related leukemias, we analyzed a cohort of 12 patients collected from across Europe who developed APL following the use of single agent mitoxantrone to treat a benign condition, multiple sclerosis (MS), and in whom there was no history of previous cancer. ${ }^{38}$ Chromosome 15 breakpoints again were found to cluster at position 1484 within $P M L$ intron 6. Furthermore, shared chromosome 17 breakpoints that were preferential sites of mitoxantrone-induced topoII cleavage in functional assays were identified within RARA intron 2 (Figure
1). ${ }^{38}$ The series of mitoxantrone-related t-APL cases analyzed has been further extended recently, with the chromosome 15 breakpoint found to fall within the "hotspot" region in 12 of 23 cases $(52 \%))^{33,38,39}$

Comparison of the genomic breakpoint junction regions with the native genes showed that translocations in mitoxantrone-related t-APL were reciprocal, generally without loss or gain of nucleotides. ${ }^{33,38}$ Presence of sequence homologies between $P M L$ and RARA suggests that topoII-mediated DNA damage may be repaired by the canonical nonhomologous end-joining (NHEJ) or the alternative end-joining (alt-NHEJ) pathway, which require minimal overlapping sequences between nonhomologous chromosomes to repair doublestranded DNA breaks $\left(\right.$ reviewed $\left.^{40}\right)$. Using the information derived from genomic breakpoint junction sequence analysis and in vitro cleavage assays, the knowledge that topoII introduces staggered nicks in 

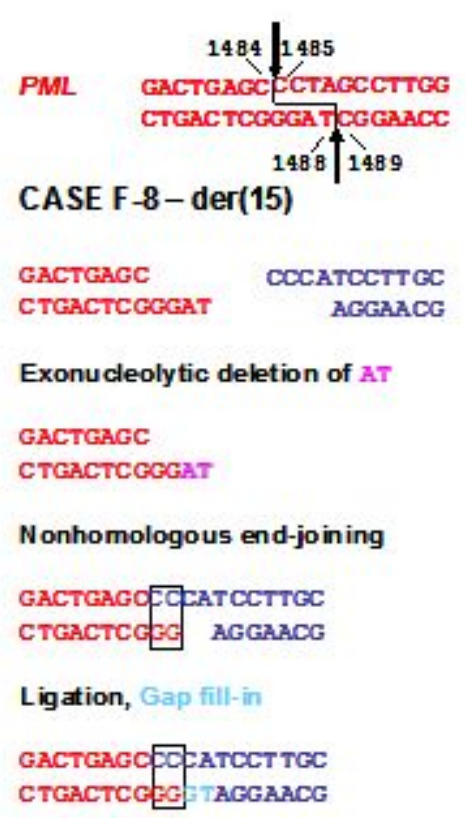
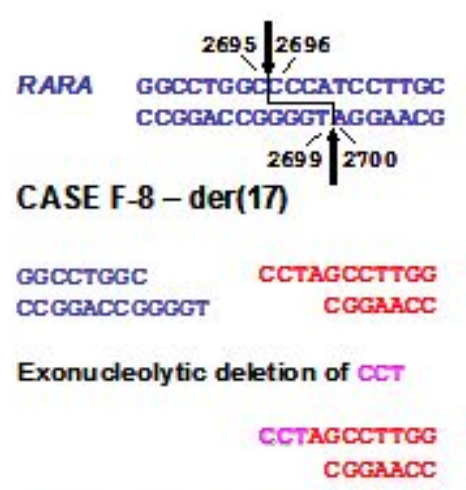

Nonhomologous end-joining

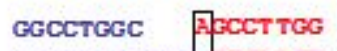

cCgGaccggge fgGaAcC

Ligation, Gap fill-in

GGCCTGGCDCC同:CT TGG CCGGACCGGGG EGGAACC

Figure 3. Model for formation of the $\mathrm{t}(15 ; 17)$ in a case of mitoxantrone-related t-APL (case F8) following topoII induced cleavage in $P M L$ and RARA loci with 4-base 5' overhangs and aberrant DNA repair. Native PML and RARA sequences are red and blue, respectively. The processing includes exonucleolytic nibbling to form two-base (der(15)) or single-base (der(17)) homologies and creation of both breakpoint junctions by error-prone nonhomologous end-joining (NHEJ). In formation of the der(15), positions 1487-1488 on the antisense strand of $P M L$ are lost by exonucleolytic nibbling (pink) before NHEJ joins the indicated bases. Positions 1485-1487 on the sense strand of $P M L$ are lost by exonucleolytic nibbling (pink) and the der(17) forms by NHEJ. Template-directed polymerization of the relevant single-stranded overhangs fills in any gaps (light blue). Each RARA overhang is preserved completely. Adapted from Mistry et al. ${ }^{33}$ with permission.

DNA with 4-bp overhangs ${ }^{22}$ and considering known mechanisms of DNA repair it was possible to construct models by which the $\mathrm{t}(15 ; 17)$ may have been formed in each case analyzed (see Figures 3 \& 4). Taken together, these data provide very strong evidence that mitoxantrone is a causative agent in the pathogenesis of t-APL.

Investigation of Molecular Mechanisms in t-APL Cases Arising Following Other TopoII Poisons. Epirubicin exposure has been linked to secondary leukemias with a range of balanced rearrangements, including translocations involving the $M L L$ locus, core binding factor leukemias and t-APL with the $\mathrm{t}(15 ; 17) .{ }^{31,41}$ In order to gain further insights into molecular mechanisms underlying epirubicin-related leukemias, we characterized $\mathrm{t}(15 ; 17)$ genomic breakpoint junction regions in a series of 6 t-APL cases that arose following breast cancer therapy. ${ }^{42}$ Epirubicin was generally used as a component of combination chemotherapy, with a median latency period from first exposure to presentation of t-APL of 26 months (range 18-48 months). Although the number of cases examined was small, significant breakpoint clustering was observed in both the $P M L$ and $R A R A$ loci $(\mathrm{P}=.009$ and $\mathrm{P}=.017$, respectively), with $P M L$ breakpoints lying outside the mitoxantrone-associated "hotspot" region (Figure 1). Functional assays demonstrated that recurrent breakpoints identified in the $P M L$ and $R A R A$ loci in epirubicin-related t-APL were preferential sites of topoII-induced DNA damage that were enhanced by epirubicin. ${ }^{42}$ Again, using the same approach as for mitoxantrone-related t-APLs, models could be constructed to explain the formation of the $t(15 ; 17)$ in APLs arising following epirubicin exposure. ${ }^{42}$

There also have been reports of t-APL occurring following treatment with other topoII poisons (e.g., etoposide) used for lymphomas and various solid tumors, as well as Langerhans cell histiocytosis. ${ }^{12,25,43}$ To determine whether topoII-mediated cleavage is relevant to other drugs associated with t-APL, we also have studied a patient in whom APL developed after treatment for laryngeal carcinoma that included etoposide and doxorubicin. ${ }^{33}$ Etoposide and its metabolites and doxorubicin induced topoII to cleave DNA at the PML and RARA translocation breakpoints. Moreover, the cleavage sites could recombine to form the der(15) and der(17) breakpoint junctions observed in this patient. Taken together, these results suggest that topoII-mediated cleavage is a general mechanism causing DNA damage in APL that develops after treatment with various agents that target topoII (Figure 

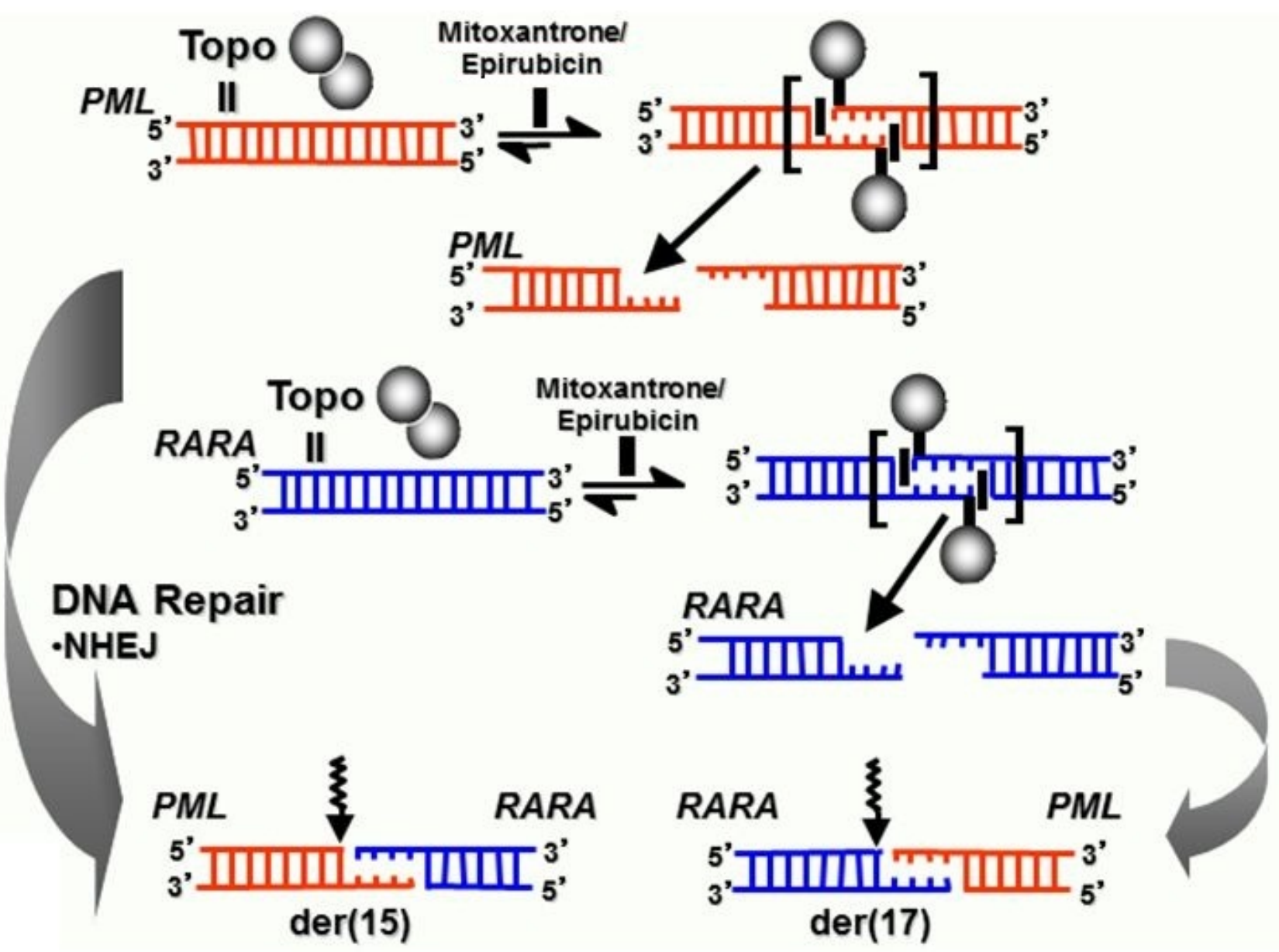

Figure 4. Model summarizing formation of reciprocal translocation breakpoint junctions in treatment related APL directly by generation of drug-stimulated topoisomerase II cleavage complexes and near-precise or precise NHEJ repair. Adapted from Felix et al. ${ }^{22}$ with permission.

4).

Concluding Remarks. While therapy-related leukemias are still relatively uncommon, they are characterized by the same range of cytogenetic abnormalities that are found in cases of AML arising de novo. ${ }^{44,45}$ Indeed, greater understanding of therapyrelated leukemias may provide significant insights into the biology of their de novo counterparts. For example, defining the latency period between first exposure to a leukemogenic agent (e.g. mitoxantrone) and presentation with full blown leukemia, provides clues to the timeframe between acquisition of chromosomal rearrangements such as the $\mathrm{t}(15 ; 17)$ and progression to leukemia in the de novo setting. Analysis of t-APL cases suggests that the median time to develop APL from the formation of the $\mathrm{t}(15 ; 17)$ is $\sim 27$ months, $33,38,42$ implying the need for cooperating mutations. While logistically challenging, therapy-related leukemias afford the opportunity for tracking the stepwise acquisition of mutations that are required for progression to full-blown leukemia, ${ }^{46,47}$ and which may be of relevance to the pathogenesis of leukemias arising de novo. While we have observed a few cases of $\mathrm{t}$-APL that present within 12 months from first mitoxantrone exposure, latency periods in the majority of cases are much longer. This may account for why, even if the $\mathrm{t}(15 ; 17)$ were acquired in some cases in utero, de novo pediatric APL only very rarely presents in infancy.

A number of studies conducted over the last three decades have served to identify specific dosing schedules or particular agents that are associated with high rates of induction of secondary leukemias, ${ }^{32,48-51}$ leading to the development of effective alternative treatment protocols that are substantially safer. ${ }^{52-54}$ However, the study of patients with t-APL has demonstrated that therapy-related leukemias also can occur in patients subject to very low level exposure, as exemplified by a case of APL involving the PML breakpoint "hotspot" arising following a single $15 \mathrm{mg}$ dose of mitoxantrone used as adjuvant chemotherapy for breast cancer. ${ }^{33}$ Epidemiology studies conducted in MS patients treated with mitoxantrone have suggested that the risk of development of secondary leukemia is $\sim 1$ in $370,{ }^{55,56}$ with the majority of reported cases being t-APL. This raises key questions as to the extent to which the play of chance is involved in the 
development of therapy-related leukemias, as well as the relative importance of patient predisposition to the development of this complication. A number of prerequisites have to be satisfied to develop leukemia following treatment with a topoII poison. Firstly, double-strand DNA breaks must occur within two genes with the potential to form oncogenic fusions. These breaks then need to be repaired to generate inframe functional chimeric fusion genes. This translocation event needs to occur in a progenitor permissive for leukemic transformation and finally the necessary cooperating mutations are acquired. While our studies have provided evidence that topoII plays a direct role in mediating DNA damage that leads to formation of the $\mathrm{t}(15 ; 17)$ in t-APL, a key question remains as to whether the enzyme is also involved in the formation of chromosomal translocations in de novo leukemias. Exposure to environmental toxins and agents targeting topoII has been implicated in the development of infant leukemia with translocations involving $M L L$ at $11 \mathrm{q} 23 .^{57-59}$ Interestingly, recent evidence lends further support for topoII in the etiology of chromosomal translocations, inducing DNA damage in the TMPRSS2 and ERG loci in response to androgen signalling, leading to formation of fusion genes involved in prostate cancer. ${ }^{60}$

It is readily conceivable that genetic susceptibility to primary tumors due to mutations or functional variants for example in DNA repair pathways also could increase the risk of development of secondary leukemias. Interestingly, a recent genome-wide association study has implicated variants in the PRDM1 gene at $6 \mathrm{q} 21$ in the development of second neoplasms in children treated with radiotherapy for Hodgkin's disease, ${ }^{61}$ whereas whole genome sequencing applied in a case of therapy-related AML arising from early-onset BRCA1/2 mutation-negative breast and ovarian cancer revealed a novel TP53 cancer susceptibility mutation. ${ }^{62}$ The spectrum of resultant

\section{References:}

1. Smith ML, Hills RK, Grimwade D. Independent prognostic variables in acute myeloid leukaemia. Blood Rev 2011; 25:3951. http://dx.doi.org/10.1016/j.blre.2010.10.002 PMid:21078537

2. Mitelman Database of Chromosome Aberrations and Gene Fusions in Cancer (2011). Mitelman F, Johansson B, and Mertens F. (Eds.), http://cgap.nci.nih.gov/Chromosomes/Mitelman

3. Zhang Y, Rowley JD. Chromatin structural elements and chromosomal translocations in leukemia. DNA Repair (Amst). 2006; 5:1282-97. http://dx.doi.org/10.1016/j.dnarep.2006.05.020 PMid:16893685

4. Ahuja HG, Felix CA, Aplan PD. Potential role of DNA topoisomerase 11 poisons in the generation of $\mathrm{t}(11 ; 20)(\mathrm{p} 15 ; \mathrm{q} 11)$ translocations. Genes Chromosomes Cancer 2000; 29:96-105. http://dx.doi.org/10.1002/1098-2264(2000)9999:9999<::AIDGCC1013>3.0.CO;2-T

5. Pedersen-Bjergaard J, Andersen, MK, Christiansen DH, Nerlov C. Genetic pathways in therapy-related myelodysplasia and acute leukemias could reflect the nature of the genetic susceptibility as well as the agents preferentially used for the particular primary condition, as would be suggested by the propensity of etoposide to induce secondary leukemias involving the $M L L$ gene at $11 \mathrm{q} 23$ and epirubicin and mitoxantrone to induce t-APL. Moreover, genetic variation in the handling of a range of specific cytotoxic agents could affect an individual's risk of developing secondary leukemia (reviewed ${ }^{63}$ ). Indeed, it has recently been reported that genetic variants of genes encoding drug-metabolizing enzymes and components of DNA repair pathways are associated with increased susceptibility to development of t-APL in patients with MS receiving mitoxantrone. ${ }^{64}$

Dissecting out the relative importance of these factors represents a considerable challenge. It requires the analysis of substantial patient cohorts, which are well characterized both in terms of their primary tumors, prior cytotoxic therapy and cytogenetic and molecular profile of the secondary leukemias. Nevertheless, significant progress in this research area is likely to be fruitful allowing not only the development of more individualized and safer approaches to treatment of primary tumors, but also (potentially) providing insights into molecular mechanisms underlying the pathogenesis of de novo leukemias. Thus, it could afford improved understanding of AML as a whole.

Acknowledgements. DG gratefully acknowledges Leukaemia \& Lymphoma Research for support, with award of Gordon Piller Studentships to Ashley Mays and Melanie Joannides. We also acknowledge support from the Genetics theme of the Guy's and St. Thomas' NHS Foundation Trust National Institute for Health Research (NIHR) Biomedical Research Centre. NO acknowledges support by National Institutes of Health grant GM033944.

myeloid leukemia. Blood 2002; 99:1909-1912 http://dx.doi.org/10.1182/blood.V99.6.1909 PMid:11877259

6. Pedersen-Bjergaard, J, Andersen, MK, Andersen, MT, Christiansen DH. Genetics of therapy related myelodysplasia and acute myeloid leukemia. Leukemia 2008; 22: 240-248. http://dx.doi.org/10.1038/sj.leu.2405078 PMid:18200041

7. Rowley JD, Olney H. International workshop on the relationship of prior therapy to balanced chromosome aberrations in therapy related myelodysplastic syndromes and acute leukemia: overview report. Genes Chromosomes Cancer 2002; 33:331-345. http://dx.doi.org/10.1002/gcc.10040 PMid:11921269

8. Larson RA, Le Beau MM. Therapy-related myeloid leukaemia: a model for leukemogenesis in humans. Chem Biol Interact. 2005; 153-154:187-95. http://dx.doi.org/10.1016/j.cbi.2005.03.023 PMid:15935816

9. Allan JM, Travis LB. Mechanisms of therapy related carcinogenesis. Nature Reviews 2005; 5:943-955. http://dx.doi.org/10.1038/nrc1749 PMid:16294218 
10. Bloomfield CD, Archer KJ, Mrózek K, Lillington DM, Kaneko Y, Head DR, Dal Cin P, Raimondi SC. 11q23 balanced chromosome aberrations in treatment-related myelodysplastic syndromes and acute leukemia: report from an International Workshop. Genes Chromosomes Cancer 2002; 33:362-78. http://dx.doi.org/10.1002/gcc.10046 PMid:11921271

11. Slovak ML, Bedell V, Popplewell L, Arber DA, Schoch C, Slater R. 21q22 balanced chromosome aberrations in therapyrelated hematopoietic disorders: report from an International Workshop. Genes Chromosomes Cancer 2002; 33:379-94. http://dx.doi.org/10.1002/gcc.10042 PMid:11921272

12. Andersen MK, Larson RA, Mauritzson N, Schnittger S, Jhanwar SC, Pedersen-Bjergaard J. Balanced chromosome abnormalities inv(16) and $\mathrm{t}(15 ; 17)$ in therapy-related myelodysplastic syndromes and acute leukemia: report from an international workshop. Genes Chromosomes Cancer. 2002; 33:395-400. http://dx.doi.org/10.1002/gcc.10043 PMid:11921273

13. Romana SP, Radford-Weiss I, Ben Abdelali R, Schluth C, Petit A, Dastugue N, Talmant P, Bilhou-Nabera C, Mugneret F, Lafage-Pochitaloff M, Mozziconacci MJ, Andrieu J, Lai JL, Terre C, Rack K, Cornillet-Lefebvre P, Luquet I, Nadal N, Nguyen-Khac F, Perot C, Van den Akker J, Fert-Ferrer S, Cabrol C, Charrin C, Tigaud I, Poirel H, Vekemans M, Bernard OA, Berger R; Groupe Francophone de Cytogénétique Hématologique. NUP98 rearrangements in hematopoietic malignancies: a study of the Groupe Francophone de Cytogénétique Hématologique. Leukemia. 2006; 20:696-706. http://dx.doi.org/10.1038/sj.leu.2404130 PMid:16467868

14. Deweese JE, Osheroff N. The DNA cleavage reaction of topoisomerase II: wolf in sheep's clothing. Nucleic Acids Res. 2009; 37:738-48. http://dx.doi.org/10.1093/nar/gkn937 PMid:19042970 PMCid:2647315

15. Mori H, Colman SM, Xiao Z, Ford AM, Healy LE, Donaldson C, Hows JM, Navarrete C, Greaves M. Chromosome translocations and covert leukemic clones are generated during normal fetal development. Proc Natl Acad Sci U S A 2002; 99: 8242-8247. PMid:12048236 PMCid:123052

16. Basecke J, Cepek L, Mannhalter C, Krauter J, Hildenhagen S, Brittinger G, Trumper L, Griesinger F. Transcription of AML1/ETO in bone marrow and cord blood of individuals without acute myelogenous leukemia. Blood 2002; 100:22672268 .

http://dx.doi.org/10.1182/blood-2002-06-1673 PMid:12229881

17. Stanulla M, Wang J, Chervinsky DS, Thandla S, Aplan PD. DNA cleavage within the MLL breakpoint cluster region is a specific event which occurs as part of higher-order chromatin fragmentation during the initial stages of apoptosis. Mol Cell Biol 1997; 17:4070-4079. PMid:9199342 PMCid:232260

18. Betti CJ, Villalobos MJ, Diaz MO, Vaughan AT. Apoptotic triggers initiate translocations within the MLL gene involving nonhomologous end joining repair system. Cancer Res 2001; 61:4550-4555. PMid:11389089

19. Betti CJ, Villalobos MJ, Diaz MO, Vaughan AT. Apoptotic stimuli initiate MLL-AF9 translocations that are transcribed in cells capable of division. Cancer Res 2003; 63: 1377-1381. PMid:12649202

20. Sim SP, Liu LF. Nucleolytic cleavage of the mixed lineage leukemia breakpoint cluster region during apoptosis. J Biol Chem 2001; 276:31590-31595. http://dx.doi.org/10.1074/jbc.M103962200 PMid:11406628

21. Scharf S, Zech J, Bursen A, Schraets D, Oliver PL, Kliem S, Pfitzner E, Gillert E, Dingermann T, Marschalek R. Transcription linked to recombination: a gene-internal promoter coincides with the recombination hot spot II of the human MLL gene. Oncogene. 2007; 26:1361-71. http://dx.doi.org/10.1038/sj.onc.1209948 PMid:16983345

22. Felix CA, Kolaris CP, Osheroff N. Topoisomerase II and the etiology of chromosomal translocations. DNA Repair (Amst) 2006; 5:1093-108. http://dx.doi.org/10.1016/i.dnarep.2006.05.031 PMid:16857431

23. Andersen MK, Johansson B, Larsen SO, Pedersen-Bjergaard J. Chromosomal abnormalities in secondary MDS and AML. Relationship to drugs and radiation with specific emphasis on the balanced rearrangements. Haematologica. 1998; 83:483-8. PMid:9676019
24. Sung PA, Libura J, Richardson C. Etoposide and illegitimate DNA double-strand break repair in the generation of MLL translocations: new insights and new questions. DNA Repair (Amst). 2006; 5:1109-18 http://dx.doi.org/10.1016/j.dnarep.2006.05.018 PMid:16809075

25. Beaumont M, Sanz M, Carli PM, Maloisel F, Thomas X, Detourmignies L, Guerci A, Gratecos N, Rayon C, San Miguel J, Odriozola J, Cahn JY, Huguet F, Vekhof A, Stamatoulas A, Dombret H, Capote F, Esteve J, Stoppa AM, Fenaux P. Therapyrelated acute promyelocytic leukemia. J Clin Oncol 2003; 21:2123-37. $\quad$ http://dx.doi.org/10.1200/JCO.2003.09.072 PMid:12775738

26. Pulsoni A, Pagano L, Lo Coco F, Avvisati G, Mele L, Di Bona E, Invernizzi R, Leoni F, Marmont F, Mele A, Melillo L, Nosari AM, Pogliani EM, Vignetti M, Visani G, Zagonel V, Leone G, Mandelli F. Clinicobiological features and outcome of acute promyelocytic leukemia occurring as a second tumor: the GIMEMA experience. Blood. 2002;100:1972-6. http://dx.doi.org/10.1182/blood-2001-12-0312 PMid:12200354

27. Mistry AR, Pedersen EW, Solomon E, Grimwade D. The molecular pathogenesis of acute promyelocytic leukaemia: implications for the clinical management of the disease. Blood Rev. 2003; 17:71-97. http://dx.doi.org/10.1016/S0268960X(02)00075-9

28. de Thé H, Chen Z. Acute promyelocytic leukaemia: novel insights into the mechanisms of cure. Nat Rev Cancer. 2010; 10:775-83. http://dx.doi.org/10.1038/nrc2943 PMid:20966922

29. Sanz MA, Grimwade D, Tallman MS, Lowenberg B, Fenaux P, Estey EH, Naoe T, Lengfelder E, Büchner T, Döhner H, Burnett AK, Lo-Coco F. Management of acute promyelocytic leukemia: Recommendations from an expert panel on behalf of the European LeukemiaNet. Blood 2009; 113:1875-1891. http://dx.doi.org/10.1182/blood-2008-04-150250 PMid:18812465

30. Carli PM, Sgro C, Parchin-Geneste N, Isambert N, Mugneret F, Girodon F, Maynadie M. Increase therapy-related leukemia secondary to breast cancer. Leukemia 2000; 14:1014-7. http://dx.doi.org/10.1038/sj.leu.2401787 PMid:10865966

31. Praga C, Bergh J, Bliss J, Bonneterre J, Cesana B, Coombes RC, Fargeot P, Folin A, Fumoleau P, Giuliani R, Kerbrat P, Hery M, Nilsson J, Onida F, Piccart M, Shepherd L, Therasse P, Wils J, Rogers D.Risk of acute myeloid leukemia and myelodysplastic syndrome in trials of adjuvant epirubicin for early breast cancer: Correlation with doses of epirubicin and cyclophosphamide. $\mathrm{J}$ Clin Oncol 2005; 23: 4179-4191. http://dx.doi.org/10.1200/JCO.2005.05.029 PMid:15961765

32. Leone G, Luca M, Alessandro P, Equitani F, Pagano, L. The incidence of secondary leukaemias. Hematologica 1999; 84:937945.

33. Mistry AR, Felix CA, Whitmarsh RJ, Mason A, Reiter A, Cassinat B, Parry A, Walz C, Wiemels JL, Segal MR, Adès L, Blair IA, Osheroff N, Peniket AJ, Lafage-Pochitaloff M, Cross NC, Chomienne C, Solomon E, Fenaux P, Grimwade D. DNA topoisomerase II in therapy-related acute promyelocytic leukemia. N Engl J Med 2005; 352:1529-38. http://dx.doi.org/10.1056/NEJMoa042715 PMid:15829534

34. Grimwade D, Jovanovic JV, Hills RK, Nugent EA, Patel Y, Flora R, Diverio D, Jones K, Aslett H, Batson E, Rennie K, Angell R, Clark RE, Solomon E, Lo-Coco F, Wheatley K, Burnett AK. Prospective minimal residual disease monitoring to predict relapse of acute promyelocytic leukemia and to direct pre-emptive arsenic trioxide therapy. J Clin Oncol, 2009; 27:3650-8. $\quad$ http://dx.doi.org/10.1200/JCO.2008.20.1533 PMid: 19506161

35. Lovett BD, Strumberg D, Blair IA, Pang S, Burden DA, Megonigal MD, Rappaport EF, Rebbeck TR, Osheroff N, Pommier YG, Felix CA. Etoposide metabolites enhance DNA topoisomerase II cleavage near leukemia-associated MLL translocation breakpoints. Biochemistry 2001; 40:1159-1170. http://dx.doi.org/10.1021/bi002361x PMid:11170441

36. Lovett BD, Lo Nigro L, Rappaport EF, Blair IA, Osheroff N, Zheng N, Megonigal MD, Williams WR, Nowell PC, Felix CA. Near-precise interchromosomal recombination and functional DNA topoisomerase II cleavage sites at MLL and AF-4 genomic breakpoints in treatment-related acute lymphoblastic leukemia with $\mathrm{t}(4 ; 11)$ translocation. Proc Natl Acad Sci USA 2001; 
98:9802-9807.

http://dx.doi.org/10.1073/pnas.171309898

PMid:11493704 PMCid:55533

37. Whitmarsh RJ, Saginario C, Zhuo Y, Hilgenfeld E, Rappaport EF, Megonigal MD, Carroll M, Liu M, Osheroff N, Cheung NK, Slater DJ, Ried T, Knutsen T, Blair IA, Felix CA. Reciprocal DNA topoisomerase II cleavage events at 5'-TATTA-3' sequences in MLL and AF-9 create homologous single-stranded overhangs that anneal to form $\operatorname{der}(11)$ and $\operatorname{der}(9)$ genomic breakpoint junctions in treatment-related AML without further processing. Oncogene 2003; 22:8448-59. http://dx.doi.org/10.1038/si.onc.1207052 PMid:14627986

38. Hasan SK, Mays AN, Ottone T, Ledda A, La Nasa G, Cattaneo C, Borlenghi E, Melillo L, Montefusco E, Cervera J, Stephen C, Satchi G, Lennard A, Libura M, Byl JA, Osheroff N, Amadori S, Felix CA, Voso MT, Sperr WR, Esteve J, Sanz MA, Grimwade D, Lo Coco F. Molecular analysis of $\mathrm{t}(15 ; 17)$ genomic breakpoints in secondary acute promyelocytic leukemia arising after treatment of multiple sclerosis. Blood 2008; 112:3383$3390 . \quad$ http://dx.doi.org/10.1182/blood-2007-10-115600 PMid:18650449 PMCid:2954750

39. Hasan SK, Ottone T, Schlenk RF, Xiao Y, Wiemels JL, Mitra ME, Bernasconi P, Di Raimondo F, Stanghellini MT, Marco P, Mays AN, Döhner H, Sanz MA, Amadori S, Grimwade D, LoCoco F. Analysis of $\mathrm{t}(15 ; 17)$ chromosomal breakpoint sequences in therapy-related versus de novo acute promyelocytic leukemia: association of DNA breaks with specific DNA motifs at PML and RARA loci. Genes Chromosomes Cancer. 2010; 49:726-32. http://dx.doi.org/10.1002/gcc.20783 PMid:20544846

40. Kass EM, Jasin M. Collaboration and competition between DNA double-strand break repair pathways. FEBS Lett. 2010; 584:3703-8. http://dx.doi.org/10.1016/i.febslet.2010.07.057 PMid:20691183

41. Pedersen-Bjergaard J, Sigsgaard TC, Nielsen D, Gjedde SB, Philip P, Hansen M, Larsen SO, Rørth M, Mouridsen H, Dombernowsky P. Acute monocytic or myelomonocytic leukemia with balanced chromosome translocations to band 11 q23 after therapy with 4-epi-doxorubicin and cisplatin or cyclophosphamide for breast cancer. J Clin Oncol. 1992; 10:1444-51. PMid:1517787

42. Mays AN, Osheroff N, Xiao Y, Wiemels JL, Felix CA, Byl JAW, Saravanamuttu K, Peniket A, Corser R, Chang C, Hoyle C, Parker AN, Hasan SK, Lo-Coco F, Solomon E, Grimwade D. Evidence for direct involvement of epirubicin in the formation of chromosomal translocations in $\mathrm{t}(15 ; 17)$ therapy-related acute promyelocytic leukemia. Blood 2010; 115:326-30. http://dx.doi.org/10.1182/blood-2009-07-235051

PMid:19884644 PMCid:2808156

43. Kudo K, Yoshida H, Kiyoi H, Numata S, Horibe K, Naoe T. Etoposide-related acute promyelocytic leukemia. Leukemia. 1998; 12:1171-5. $\quad$ http://dx.doi.org/10.1038/sj.leu.2401089 PMid:9697869

44. Smith SM, Le Beau MM, Huo D, Karrison T, Sobecks RM, Anastasi J, Vardiman JW, Rowley JD, Larson RA. Clinicalcytogenetic associations in 306 patients with therapy-related myelodysplasia and myeloid leukemia: the University of Chicago series. Blood. 2003; 102:43-52. http://dx.doi.org/10.1182/blood-2002-11-3343 PMid:12623843

45. Kayser S, Döhner K, Krauter J, Köhne CH, Horst HA, Held G, von Lilienfeld-Toal $M$, Wilhelm $S$, Kündgen $A$, Götze $K$, Rummel M, Nachbaur D, Schlegelberger B, Göhring G, Späth D, Morlok C, Zucknick M, Ganser A, Döhner H, Schlenk RF; German-Austrian AMLSG. The impact of therapy-related acute myeloid leukemia (AML) on outcome in 2853 adult patients with newly diagnosed AML. Blood. 2011; 117:2137-45. http://dx.doi.org/10.1182/blood-2010-08-301713 PMid:21127174

46. Megonigal MD, Cheung NK, Rappaport EF, Nowell PC, Wilson RB, Jones DH, Addya K, Leonard DG, Kushner BH, Williams TM, Lange BJ, Felix CA. Detection of leukemia-associated MLL-GAS7 translocation early during chemotherapy with DNA topoisomerase II inhibitors. Proc Natl Acad Sci U S A. 2000; 97:2814-9. $\quad$ http://dx.doi.org/10.1073/pnas.050397097 PMid:10706619

47. Robinson BW, Cheung NK, Kolaris CP, Jhanwar SC, Choi JK, Osheroff N, Felix CA. Prospective tracing of MLL-FRYL clone with low MEIS1 expression from emergence during neuroblastoma treatment to diagnosis of myelodysplastic syndrome. Blood. 2008; 111:3802-12. http://dx.doi.org/10.1182/blood-2007-07-096065 PMid:18195096 PMCid:2275033

48. Pedersen-Bjergaard J. Long-term complications of cancer chemotherapy. J Clin Oncol. 1995; 13:1534-6. PMid:7602341

49. Smith MA, Rubinstein L, Ungerleider RS. Therapy-related acute myeloid leukemia following treatment with epipodophyllotoxins: estimating the risks. Med Pediatr Oncol. 1994; 23:86-98 http://dx.doi.org/10.1002/mpo.2950230205 PMid:8202047

50. Smith RE. Risk for the development of treatment-related acute myelocytic leukemia and myelodysplastic syndrome among patients with breast cancer: review of the literature and the National Surgical Adjuvant Breast and Bowel Project experience. Clin Breast Cancer. 2003; 4:273-9. http://dx.doi.org/10.3816/CBC.2003.n.032 PMid:14651772

51. Leone G, Pagano L, Ben-Yehuda D, Voso MT. Therapy-related leukemia and myelodysplasia: susceptibility and incidence. Haematologica. 2007; 92:1389-98. http://dx.doi.org/10.3324/haematol.11034 PMid:17768113

52. Pui CH, Pei D, Sandlund JT, Ribeiro RC, Rubnitz JE, Raimondi SC, Onciu M, Campana D, Kun LE, Jeha S, Cheng C, Howard SC, Metzger ML, Bhojwani D, Downing JR, Evans WE, Relling MV. Long-term results of St Jude Total Therapy Studies 11, 12 $13 \mathrm{~A}, 13 \mathrm{~B}$, and 14 for childhood acute lymphoblastic leukemia. Leukemia. 2010; 24.371-82. http://dx.doi.org/10.1038/leu.2009.252 PMid:20010620 PMCid:2820159

53. Kushner BH, Kramer K, Modak S, Qin LX, Yataghena K, Jhanwar SC, Cheung NK. Reduced risk of secondary leukemia with fewer cycles of dose-intensive induction chemotherapy in patients with neuroblastoma. Pediatr Blood Cancer. 2009; 53:1722. http://dx.doi.org/10.1002/pbc. 21931

54. Felix CA. A safer regimen for high-risk neuroblastoma. Pediatr Blood Cancer. 2009; 53:3-6. http://dx.doi.org/10.1002/pbc.22020

55. Ghalie RG, Mauch E, Edan G, Hartung HP, Gonsette RE, Eisenmann S, Le Page E, Butine MD, De Goodkin DE. A study of therapy-related acute leukaemia after mitoxantrone therapy for multiple sclerosis. Mult Scler 2002; 8:441-445. http://dx.doi.org/10.1191/1352458502ms836oa PMid:12356214

56. Ellis R, Boggild M. Therapy-related acute leukaemia with Mitoxantrone: what is the risk and can we minimise it? Mult Scler. 2009; 15:505-8. http://dx.doi.org/10.1177/1352458508100967 PMid:19251838

57. Alexander FE, Patheal SL, Biondi A, Brandalise S, Cabrera ME, Chan LC, Chen Z, Cimino G, Cordoba JC, Gu LJ, Hussein H, Ishii E, Kamel AM, Labra S, Magalhães IQ, Mizutani S, Petridou E, de Oliveira MP, Yuen P, Wiemels JL, Greaves MF. Transplacental chemical exposure and risk of infant leukemia with MLL gene fusion. Cancer Res 2001; 61:2542-6. PMid:11289128

58. Hall GW. Childhood myeloid leukaemias. Best Pract Res Clin Haematol 2001; 14:573-91. http://dx.doi.org/10.1053/beha.2001.0155

59. Spector LG, Xie Y, Robison LL, Heerema NA, Hilden JM, Lange B, Felix CA, Davies SM, Slavin J, Potter JD, Blair CK, Reaman GH, Ross JA. Maternal diet and infant leukemia: the DNA topoisomerase II inhibitor hypothesis: a report from the children's oncology group. Cancer Epidemiol Biomarkers Prev. 2005; 14:651-5. http://dx.doi.org/10.1158/1055-9965.EPI-04$\underline{0602}$

60. Haffner MC, Aryee MJ, Toubaji A, Esopi DM, Albadine R, Gurel B, Isaacs WB, Bova GS, Liu W, Xu J, Meeker AK, Netto G, De Marzo AM, Nelson WG, Yegnasubramanian S. Androgen-induced TOP2B-mediated double-strand breaks and prostate cancer gene rearrangements. Nat Genet 2010; 42:66875. http://dx.doi.org/10.1038/ng.613 PMid:20601956 PMCid:3157086

61. Best T, Li D, Skol AD, Kirchhoff T, Jackson SA, Yasui Y, Bhatia S, Strong LC, Domchek SM, Nathanson KL, Olopade OI, Huang RS, Mack TM, Conti DV, Offit K, Cozen W, Robison LL, Onel K. Variants at 6q21 implicate PRDM1 in the etiology of therapy-induced second malignancies after Hodgkin's lymphoma. Nat Med 2011; 17:941-3. http://dx.doi.org/10.1038/nm.2407 PMid:21785431

62. Link DC, Schuettpelz LG, Shen D, Wang J, Walter MJ, Kulkarni 
S, Payton JE, Ivanovich J, Goodfellow PJ, Le Beau M, Koboldt DC, Dooling DJ, Fulton RS, Bender RH, Fulton LL, Delehaunty KD, Fronick CC, Appelbaum EL, Schmidt H, Abbott R, O'Laughlin M, Chen K, McLellan MD, Varghese N, Nagarajan R, Heath S, Graubert TA, Ding L, Ley TJ, Zambetti GP, Wilson RK, Mardis ER. Identification of a novel TP53 cancer susceptibility mutation through whole-genome sequencing of a patient with therapy-related AML. JAMA 2011; 305:1568-76.

http://dx.doi.org/10.1001/jama.2011.473 PMid:21505135 PMCid:3170052

3. Seedhouse C, Russell N. Advances in the understanding of susceptibility to treatment-related acute myeloid leukaemia. Br J Haematol 2007; 137: 513-529. http://dx.doi.org/10.1111/j.13652141.2007.06613.x PMid:17539774

64. Hasan SK, Buttari F, Ottone T, Voso MT, Hohaus S, Marasco E, Mantovani V, Garagnani P, Sanz MA, Cicconi L, Bernardi G, Centonze D, Lo-Coco F. Risk of acute promyelocytic leukemia in multiple sclerosis: coding variants of DNA repair genes. Neurology. 2011

http://dx.doi.org/10.1212/WNL.0b013e318211c3c8 PMid:21346221 